\title{
HERITAGE CONSERVATION IN ANTARCTIC AND SUBANTAR CTIC JURISDICTIONS: THE CASE OF MACQUARIE ISLAND
}

\author{
by Bruce W. Davis
}

DAVIS, B.W., 1988 (viii): Heritage conservation in antarctic and subantarctic jurisdictions: the case of Macquarie Island. Pap. Proc. R. Soc. Tasm., 122(1): 9-14. Papers presented at the Macquarie Island Symposium, Hobart, May 1987. https://doi.org/10.26749/rstpp.122.1.9 ISSN 0080-4703. Formerly University of Tasmania, now Public Policy and Administration, School of Social Inquiry, Murdoch University, Perth, W.A., Australia 6150.

Macquarie Island, in the subantarctic, is in a position of great importance for programmes of scientific research and nature conservation, but its historic value in the area of heritage conservation should also be recognised. $\mathrm{A}$ management plan should be formulated for protection of the features of the island in all these aspects.

Key Words: Macquarie Island, conservation, Antarctic Treaty.

\section{INTRODUCTION}

Most Australians know little of Macquarie Island but, if they have any vision of the place, probably assume it to be part of Antarctica teeming with wildlife. In this symposium it is important not only to place on record current knowledge about Macquarie Island, but also to explain its contextual relationship to international programmes of scientific investigation and nature conservation. It is equally essential to recognise that Antarctica and the Southern Oceans are becoming a focus of international rivalries and concern; thus subantarctic dependencies such as Macquarie Island take on a new strategic significance. This paper is intended to set the scene for more detailed expositions of characteristics of the island, but the political implications of its existence as part of Australia must also be recognised.

\section{TERRAIN AND WILDLIFE}

Other commentators will explain in their papers details of the island's topography, climate, vegetation and wildlife, but here some basic facts are outlined.

Macquarie Island was discovered in 1810 by Frederick Hasselborough in the Sydney sailing brig Perseverance (Cumpston 1968). The island is located at latitude $54^{\circ} 37^{\prime} \mathrm{S}$ and longitude $158^{\circ} 54^{\prime} \mathrm{E}$, in the Southern Ocean, approximately $1500 \mathrm{~km}$ southeast of Tasmania. When Van Diemen's Land was proclaimed in 1825, Macquarie Island was included in its charter and has subsequently been considered a subantarctic dependency of Esperance municipality, Tasmania.

The island is approximately 12343 hectares in extent, some $34 \mathrm{~km}$ long (north-south) and up to $5 \mathrm{~km}$ wide, with a rocky shoreline backed by steep hills and cliffs, which form an undulating plateau $200-300 \mathrm{~m}$ a.s.l., with a maximum altitude of $433 \mathrm{~m}$ at Mt Hamilton. There are several adjacent seastacks and offshore islets. Macquarie Island is of volcanic origin, a horst block subsequently eroded by glacial action and possessing several lakes, but with no permanent ice. The island has a cold temperate climate with strong westerly winds, heavy cloud and a rainfall of approximately $900 \mathrm{~mm}$ per year.

There are no trees, but the island is extensively vegetated with tussock grasslands, herbs and sedges, and areas of peatbog. Numerous varieties of birds, penguins, elephant seals and fur seals abound; indeed, Macquarie Island is one of the great wildlife preserves of the world. Unfortunately, there are also some feral species, such as mice, rats, cats and rabbits; a mere remnant of diverse species introduced by man at various stages since 1810 . Early interest in the island was entirely commercial, based on exploitation of penguin and seal resources for fur and oil. Macquarie Island was declared a sanctuary in 1933 and the only human habitation now extant is an Australian National Antarctic Research Expedition (ANARE) base in the north of the island, intended for meteorological and scientific use.

\section{PROTECTION}

Scientists began visiting Macquarie Island from 1833 onwards, and during the 1911-14 Australasian Antarctic Expedition (AAE), Sir Douglas Mawson established the first major scientific research station on the island. The efforts of various scientists, but principally Mawson, brought commercial exploitation of wildlife to a close by 1919 and in 1933 the Tasmanian Government declared the island to be a Wildlife Sanctuary 
under $t$ he Animals and Birds Protewion Act 1928. It was s ubsequently gazetted a State Reserve under the Tasmanian National Parks and Wildlife Ac 1970, which came into effect in 1971-72, and in 1978 overall protection was upgraded to that of a Nature Reserve. All wildlife and natural feaures are now conserved and entry to the reserve is by permit. Alteration of regulations or sny attemptat revocation of part of the reserve wowld require the assent of both Houses of the Tasmanian Parliament, so security of protection is high (TNPWS Report 1980). A detailed management plan is currently in preparation.

\section{BIOSPHERE RESERVE STATUS}

Macquarie Island is one of the twelve biosphere reserves within Australian jurisdiction, hav ing been granted this status by the United Nations Educational, Scientific and Cultural Organisation (UNESCO) in October 1977, as part of its Man and Biosphere (MAB) programme (Rounsevell \& Copson 1985). Biosphere reserves are areas which, because of their characteristic plants and animals, and the way they are used by people, provide scientific reference points to compare human impacts on the environment with the effects of natural forces. A biosphere reserve therefore contains both relatively pristine areas and zones which have been modified by human activity, scientific monitoring being used to assess the differences. There is usually a protected core of relatively undisturbed terrain and one or more "buffer zones" in which experimental work is carried out (Davis \& Drake 1983).

How are biosphere reserves different from other protected areas? The International Union for the Conservation of Nature (IUCN) recognises ten different types of protected areas, each with particular characteristics (IUCN 1978):

\begin{tabular}{|c|c|}
\hline Category I & $\begin{array}{l}\text { Scientific reserve/strict nature } \\
\text { reserve }\end{array}$ \\
\hline Category II & National Park \\
\hline Category III & $\begin{array}{l}\text { Natural monument/national } \\
\text { landmark }\end{array}$ \\
\hline Category IV & $\begin{array}{l}\text { Nature conservation } \\
\text { reserve/ wildlife sanctuary }\end{array}$ \\
\hline Category $\mathrm{V}$ & Protected landscape \\
\hline Category VI & Resource reserve \\
\hline Category VII & $\begin{array}{l}\text { Natural biotic } \\
\text { area/anthropological reserves }\end{array}$ \\
\hline Cate & Multiple-use management area \\
\hline Categ & Biosphere reserve \\
\hline Category $\mathrm{X}$ & World Heritage site (natural). \\
\hline
\end{tabular}

It is fairly obvious that Macquarie Island could qualify for any or all of Categories I, II, IV or IX status, but overall the reserve possesses qualities mainly evident in Categories I and $\mathrm{X}$, being a strict nature reserve, with limited areas assigned for scientific monitoring and investigation.

Australia's systern of biosphere reserves has an important intemational value in seting reference points for assessing ari qualiy, pollution and radioactivity levels, neteorological effects, the impact of introduced species and environmental damage caused by human activities. There are, however, many deficiencies and omissions in Australian monitoring programmes (Davis 1986a), and it cannot be argued that asystematic and thematic investigation plan exists for Macquarie Island as yet. A recent report on the conservation of subantarctic islands, prepared by an IUCN/ SCAR (Scientific Committee on Antarctic Research) workshop (SCAR/IUCN 1986) does provide guidelines which should be followed in the future. Details of the principal recommendations are given as Appendix $A$ of this paper.

\section{ANTARCTIC TREATY PROVISIONS}

The Antarctic Convergence lies some 200$250 \mathrm{~km}$ south of Macquarie Island; thus the nature reserve does not form part of Antarctica or automatically come under provisions of the Antarctic Treaty of 1959. In practice, however, there is a sensible and necessary connection. Many of the scientific programmes carried out on Macquarie Island are operated by personnel with antarctic interests, projects and experience; moreover, the data collected link in the comparative material from other subantarctic dependencies and the Antarctic Continent itself (Antarctic Division 1987). This is not to suggest that all research has antarctic implications, but the nexus is considerable and strengthening.

The three principles upon which the Antarctic Treaty is based, namely demilitarisation, international scientific co-operation and environmental protection, are as pertinent to Macquarie Island as to the frozen continent further south. These precepts are further reinforced by Australian statutes regulating research in Antarctica and subantarctic islands such as Heard, McDonald (Keage I981) and Macquarie. The relevant legislation is as follows:

the Wildlife Protection (Restriction of Exports and Imports) Act 1982; 
- the Whale Protection Act 1980;

- the Environmental Protection (Impact of Proposals) Act 1974;

- the Quarantine Act 1908.

In addition, two statutes exist which give effect to agreements under the Antarctic Treaty system:

- the Antarctic Treaty (Environment Protection) Act 1980;

the Antarctic Marine Living Resources Conservation Act 1981.

As we shall discover later, some aspects of the Australian Heritage Commission Act 1975 are also relevant.

\section{CAMLR}

The Convention on the Conservation of Antarctic Marine Living Resources (CAMLR) was signed in Canberra on 21 May 1980 and came into force on 7 April 1982. The fifteen original contracting parties included all thirteen full members of the Antarctic Treaty, together with the Federal Republic of Germany and the German Democratic Republic. The convention is widely acknowledged by member states to be part of the Antarctic Treaty system and operates south of $60^{\circ}$ latitude and the Antarctic Convergence. Its primary aim is to secure international co-operation in marine research and ensure the conservation of particular fish species and the ecosystems upon which they depend (Commission CAMLR 1984). In recent times the Australian Government has expressed concern about slow implementation of the Convention, particularly ecosystems management; nonetheless, some achievements have been recorded and more are in prospect (Commonwealth of Australia 1985).

In theory, CAMLR does not apply to the waters surrounding Macquarie Island, but in practice there is a linkage through marine research programmes in the Southern Ocean. Australia is permitted to declare a 200-mile economic zone around Macquarie Island, under the provisions of UNCLOS III (the Law of the Sea), but has not yet done so. However, a 200-mile fishing zone does apply, although it is difficult to envisage how this could be effectively monitored or enforced. In brief, our knowledge of marine resources adjacent to Macquarie Island is scant and needs to be improved in the future.

\section{HERITAGE CONSERVATION}

Thus far, the paper has focussed on aspects of nature conservation and scientific research on Macquarie Island, but this neglects another important dimension, namely heritage conservation. Here we are concerned with aspects such as historic shipwrecks, industrial archaeology and the built environment, as much as natural features. The Australian Heritage Commission, a federal statutory authority established in 1975 , has jurisdiction in this field. The Commission is responsible for advising the Federal Government about policy relating to conservation of the natural, built and cultural environment, and also compiles an inventory of significant places, known as the Register of the National Estate. The latter is defined (Australian Heritage Commission 1985) as “... those places being components of the natural environment of Australia or the cultural environment that have aesthetic, historic, scientific or social significance or other special value for future generations as well as the present community".

Except in special circumstances, listing of a place only highlights its significance and does not preclude any private owner, state or local government from exercising judgement about use of the place; however, the Act does bind the Commonwealth in a number of ways.

Section 30 of the Australian Heritage Commission Act 1975 requires all Federal Ministers to conserve National Estate values. Thus, if a Commonwealth action will impact upon listed places, ministers must examine the situation, consult the Commission and take all prudent and feasible measures which will conserve the essential heritage characteristics of the area. Since Macquarie Island is listed on the Register of the National Estate, Federal agencies and employees are enjoined to minimise human impacts upon biota, natural features, marine or industrial relics or historic buildings. The work of documenting and listing specific sites and artefacts on Macquarie Island is far from complete, but was described in other contributions to this symposium.

\section{STRATEGIC IMPLICATIONS}

It is tempting to assume that Macquarie Island will remain a windswept, hostile but fascinating wildlife refuge, with little human occupation or impact, but the island must be viewed against the broader spectrum of international rivalries and global politics. Although Antarctica is frequently depicted as a zone of peace, there are rival territorial 
claims and underlying political tensions; more nations are becoming interested in the region and wish to have some say in its management (Beck 1986, Hall 1986). The question is whether the Treaty is robust or flexible enough to meet new demand sin the years ahead. Similarly, the CAMLR convention is under test and the Law of the Sea has induced some developing nations to seek a share in the spoils, through "common heritage" arguments (Davis 1986b). In brief, we must be cognisant with the reality that Macquarie Island could have an importance beyond its natural beauty; that in formulating management plans for the island, state, national and international factors must be considered and the political implications of actions carefully weighed.

The stark grandeur of Macquarie Island, once witnessed, is not easily forgotten. May it continue to be haven of peaceful scientific research, aesthetic inspiration and wildlife conservation.

\section{REFERENCES}

ANTARCTIC DIVISION, 1987: APPROVED ANARE SCIENCE PROGRAMME 1986-87. Department of Science, Canberra.

AUSTRALIAN HERITAGE COMMISSION, 1985: AUSTRALIA'S NATIONAL ESTATE: THE ROLE OF THE COMMONWEALTH. Australian Government Publishing Service, Canberra.

BECK, P.J., 1986: Challenges to the Antarctic Treaty regime: The external political challenge. In Millar, T.B. (Ed.): AUSTRALIA, BRITAIN AND ANTARCTICA. Australian Studies Centre, Institute of Commonwealth Studies, University of London: 60-79.

COMMISSION CAMLR, 1984: BASIC DOCUMENTS OF THE CAMLR CONVENTION. CAMLR Secretariat, Hobart.

COMMONWEALTH OF AUSTRALIA, 1983: THE ANTA RCTIC TREATY SYSTEM. Australian Government Publishing Service, Canberra.

COMMONWEALTH OF AUSTRALIA, SENATE STANDING COMMITTEE ON NATURAL
RESOURCES, 1985: THE NATURAL RESOURCES OF THE AUSTRALIAN ANTARCTIC TERRITORY. AGPS, Canberra.

CUMPSTON, J.S., 1968: Macquarie Island. ANARE Sci. Rep., Ser. A(1). Antarctic Division, Department of External Affairs, Melbourne.

DAVIS, B.W., 1986a: The contribution of the social sciences to Australian antarctic research. $A S A C$ FORUM, PAPERS AND SUBMISSIONS, Vol.2. Department of Science, Canberra, October 1986.

DAVIS, B.W., 1986b: Antarctica: Background to the present situation. In Millar, T.B. (Ed.): $A U S$ TRALIA, BRITAIN AND ANTARCTICA. Australian Studies Centre, Institute of Commonwealth Studies, University of London: 4-18.

DAVIS, B.W. \& DRAKE, G.A., 1983: AUSTRALIA'S BIOSPHERE RESERVES: CONSERVING ECOLOGICAL DIVERSITY. Australian National Commission for UNESCO, Australian Government Publishing Service, Canberra.

HALL, R., 1986: Antarctica in World Politics. Unpub- lished M.A. thesis, University of Tasmania.

IUCN, 1978: CATEGORIES, OBJECTIVES AND CRITERIA FOR PROTECTED AREAS. Morges, Switzerland.

JOHNSTONE, G.W., 1985: Threats to birds on subantarctic islands. ICPB (International Council for Bird Preservation) Tech. Bull., No.3.

KEAGE, P.L. 1981: THE CONSERVATION STATUS OF HEARD ISLAND AND THE MCDONALD ISLANDS. Environmental Studies, Occasional Paper 13. Centre for Environmental Studies, University of Tasmania.

ROUNSEVELL, D. \& COPSON, G., 1985: Southern ocean sanctuary. UNESCO Review, No.10, March 1985, Canberra.

SCAR/IUCN, 1986: The biological basis for conservation of subantarctic islands. REPORT OF $A$ JOINT SCAR/IUCN WORKSHOP, PAIMPONT, FRANCE, SEPTEMBER 1986

TASMANIAN NATIONAL PARKS AND WILDLIFE SERVICE, 1980: MACQUARIE ISLAND NATURE RESERVE. Hobart.

(accepted 17 February 1988) 


\section{APPENDIX A \\ CONSERVATION MEASURES FOR SUBANTARCTIC ISLANDS IUCN/ SCAR RECOMMENDATIONS, 1986}

\section{Recommendations}

The workshop made the following unanimous recommendations:

\section{Recommend}

that the severity of the impact of introduced plants and animals on these sensitive island ecosystems be urgently assessed, that appropriate control measures be instituted as soon as possible to minimise damage and that the ecosystems be monitored to assess recovery;

\section{Encourage}

national authorities to conserve, under strictly controlled conditions, a sample of those introduced species whose genetic resources are regarded as potentially useful, if this does not conflict with the conservation of endangered indigenous species.

\section{Recommend}

that all islands be protected from any new accidental introductions by Man and that all necessary inspection and quarantine procedures to ensure this be brought into use as soon as possible;

\section{Encourage}

national authorities to consider very carefully any voluntary or planned introductions of flora, fauna or soil to the islands, to subject such plans to rigorous and prior Environmental Impact Assessment, to monitor the effect of the introduction and, whenever practicable, to destroy or remove the introduction once its original purpose is complete.

\section{Recommend}

that particular consideration be given, when considering fishery controls, to the dependence of these terrestrial ecosystems on nutrient input from the Southern Ocean; that marine buffer zones should be instituted (where practicable under extant legislation) to provide some limited protection of food resources;

\section{Encourage}

appropriate national authorites to develop agreements for protection of these food chains under the Convention for the Conservation of Antarctic Marine Living Resources (CCAMLR);

\section{Recognise}

that mortality in some bird and seal species during fishing operations or by the ingestion of plastic debris gives cause for serious concern and could be minimised by appropriate national action.

\section{Recommend}

that each national authority develops and implements conservation policies and plans, devised specifically for each island or island group, and incorporating a full consideration of the control of human impact on the natural ecosystem;

\section{Encourage}

the implementation of scientific research and monitoring programmes necessary for the conservation management of the island ecosystems;

\section{Recognise}

that although achievement of the objectives of conservation plans will be subject mainly to selfassessment, the use of independent observers appointed by each national authority is likely to contribute to greater success.

\section{Recommend}

that island ecosystems as well as specific sites are accorded special legal protection to ensure their integrity is maintained;

\section{Encourage}

national authorities to identify a fully representative series of strictly protected areas of restricted access, as well as sites of special scientific interest, and to consider which areas might be proposed for international designation, as World Heritage Sites or Biosphere Reserves, for example.

\section{Recommend}

that organisation and control of stations, logistics and scientific programmes be exercised to ensure minimal impact on the natural ecosystem, and that station development be constrained within a designated area;

\section{Encourage}

national authorities to follow the SCAR guidelines on pollution control published for the Antarctic Treaty area. 


\section{Recommend}

that historical sites and artefacts of shipwreck, sealing, whaling or other human activities are mapped, documented and conserved as far as possible.

\section{Encourage}

the involvement of specialist advisors on archaeology and history in this;

\section{Recognise}

that this subject merits detailed treatment outside the remit of this workshop.

\section{Recommend}

that national authorities give immediate consideration to ensuring adequate education for all their island and ship personnel in the conservation objectives for each island in all their island groups;

\section{Encourage}

both scientists and administrators to provide public education on the significance and value of the subantarctic islands; encourage responsible and controlled tourism;

\section{Recognise}

that SCAR and especially IUCN could make an important contribution to global awareness of subantarctic conservation.

\section{Recommend}

that IUCN convene a meeting of island management authorities to discuss implementation of these recommendations;

\section{Encourage}

national authorities, operating agencies and scientists to promote free and full exchange of all information and data, especially on those aspects which concern conservation and environmental protection of these unique islands. 